\title{
FORMATION OF CORN PRODUCTIVITY IN CROP ROTATION DEPENDING ON LONG-TERM FERTILIZATION AND LIMING
}

\author{
Institute of Agriculture of the Carpathian Region of NAAS, Obroshyne, Lviv, Ukraine
}

\begin{abstract}
Corn (Zea mays L.) is one of the main source of feed and food resources. The importance of this culture in the world economy continues to grow. In Ukraine corn is an export-oriented crop of universal purpose and high potential. Based on the results of research in the ninth rotation of long-term stationary experiment, it was found that in the Western Forest-Steppe in four-field crop rotation on Albic Stagnic Luvisol the highest productivity of corn $73 \mathrm{t} \cdot \mathrm{ha}^{-1}$ is formed by organo-mineral fertilizing system with systematic joint application of $10 \mathrm{t} \cdot \mathrm{ha}^{-1}$ manure, $\mathrm{N}_{65} \mathrm{P}_{68} \mathrm{~K}_{68}$ on the background of periodic liming with $1.0 \mathrm{n} \mathrm{CaCO}_{3}$ by hydrolytic acidity. It is shown that long-term unilateral application of mineral fertilizer system (more than 50 years) on acidic soil along with the accumulation of nitrogen compounds increases the acidity and content of mobile aluminum compounds, leads to blocking the activity of enzyme systems, reducing absorption and transformation of nutrients and in consequence the formation of low-yield corn at the level of control without fertilizers.
\end{abstract}

Key words: corn, fertilizers, liming, acidity, harvest.

\section{INTRODUCTION}

The primary task of agriculture in Ukraine is the production of food and providing the industry with raw materials. In solving this problem, great importance is focused on corn (Zea mays L.) as a high-yield crop of universal purpose with valuable food, feed and technical qualities (Masliyov et al. 2018; Minkin 2019).

Growing corn for grain plays a stabilizing role in the grain complex of the country, because in unfavorable years for other grain crops, its yield is relatively high (Klimchuk 2009). However, in recent years corn is increasingly used as a renewable energy source for the production of bioethanol (from 1 ton of grain you can get 410 liters of alcohol). Also, the presence of remontant forms of corn allows effective using the leaf mass for processing (fermentation) for biogas in special plants (Klimchuk and Skoruk 2011).

At the same time, corn is a crop with high potential for green mass harvesting, especially in the Forest-Steppe conditions (Tanchik et al. 2019).

Normal development of corn plants is determined not only by the necessary reserves of moisture, but also by other factors, among which are the presence of available nutrients in the soil and, first of all, nitrogen compounds (Masliyov et al. 2018). It is established that

Corresponding author: Yuriy Olifir, Institute of Agriculture of the Carpathian Region of NAAS, Hrushevskoho street 5, Obroshyne, Pustomyty district, Lviv region, 80115 Ukraine, e-mail: olifir.yura@gmail.com 
the optimization of the nitrogen regime of the soil under the influence of different systems of fertilizing and tillage contributes to a fuller disclosure of the genetic potential of plant productivity, obtaining consistently high yields of crops (Kolos 2017).

To optimize plant nutrition conditions, a dynamic fertilizing system should be used in crop rotation. It provides the periodic scientifically sound changes in the composition, forms, doses and ratios of mineral fertilizers. It also takes into account the dynamics of soil nutrient regime and other important properties, including acidity. This ensures further crop growth and significantly increases the efficiency of fertilizers. Corn can absorb all forms of nitrogen, especially ammonia. It mobilizes and uses nutrients from sedentary soil compounds and fertilizers not only by the direct soluble action of root acids, but also by activating the vital activity of rhizosphere microorganisms and fungi (Klimchuk and Skoruk 2011).

The nitrogen regime has particular importance in the formation of the yield size and quality of the crops in the area of the Ukrainian Western Forest-Steppe, which is characterized by excessive and uneven rainfall and, as a consequence, periodically flushing water regime. On gray forest soils, which predominate in this region and are characterized by low humus content, the total nitrogen reserves do not exceed $4-5 \mathrm{t} \cdot \mathrm{ha}^{-1}$ in the humus horizon. Due to high acidity and unfavorable water-air regime, the nitrification capacity of these soils is low, and crops are experiencing a constant nitrogen deficiency. Therefore they respond well to the application of nitrogen fertilizers.

\section{MATERIAL AND METHODS}

Studies of the long-term influence of different fertilizing and liming systems on the dynamics of the nitrogen regime and the formation of corn yield were conducted in a stationary experiment of the Institute of Agriculture of the Carpathian region of NAAS. The experiment was established in 1965 on acidic Albic Stagnic Luvisol (WRB 2015) in Obroshyne, Pustomyty district, Lviv region (49 $\left.47^{\prime} 54.3^{\prime \prime} \mathrm{N} 23^{\circ} 52^{\prime} 26.9^{\prime \prime} \mathrm{E}\right)$. Entered in the register of long-term stationary field experiments of the National Academy of Agrarian Sciences of Ukraine (NAAS registration certificate No. 29). The experiment provides a combined and separate application of $0.5,1.0$ and 1.5 norm $(\mathrm{n}) \mathrm{CaCO}_{3}$ by hydrolytic acidity $(\mathrm{Ha})$, full $\left(\mathrm{N}_{65} \mathrm{P}_{68} \mathrm{~K}_{68}\right)$, half, one-and-a-half, and double doses of NPK, 10 and 20 tons of manure per 1 ha of crop rotation area (Table 1 ).

The stationary experiment is placed on three fields, each of which has 18 variants in three repetitions. The location of the variants is single-tiered, consecutive. The total area of the plot is $168 \mathrm{~m}^{2}$, accounting area $-100 \mathrm{~m}^{2}$. The crop rotation is four-field with the following alternation of crops: corn for silage - spring barley with sowing of meadow clover - meadow clover - winter wheat. Agricultural cultivation techniques, tillage and crop care are generally accepted for the conditions of the Western Forest-Steppe zone.

The experiment used semi-overripe cattle manure with straw bedding, ammonium nitrate (34.5\%), granular superphosphate (19.5\%), potassium salt (40\%), nitroammophos (NPK 16\%) (when using nitroammophos NPK content was balanced with simple fertilizers). Manure (40-60 t $\cdot \mathrm{ha}^{-1}$ ) was applied before corn. Phosphorus-potassium fertilizers were applied in autumn, and nitrogen - before pre-sowing cultivation. Liming, according to the scheme, 
was carried out before the start of the ninth rotation. The dose of fertilizer application was also adjusted before the start of the IX rotation. Limestone flour $\left(93.5 \% \mathrm{CaCO}_{3}\right)$ was used as limestone material.

The agrochemical characteristics of the arable layer of the soil before the experiment begin are as follows: humus content (according to Tyurin) $1.42 \%, \mathrm{pH}_{\mathrm{KCl}}-4.2, \mathrm{Ha}$ (according to Kappen) 4.5, metabolic acidity (according to Sokolov) $-0.6 \mathrm{mmol} \cdot \mathrm{kg}^{-1}$ of soil, the content of mobile aluminum 60.0, mobile phosphorus (according to Kirsanov) and exchangeable potassium (according to Maslova) -36.0 and $50.0 \mathrm{mg} \cdot \mathrm{kg}^{-1}$ of soil respectively.

On the studied variants of the stationary experiment (according to the experimental scheme) soil samples were taken, from which the average samples were formed and prepared for analysis in accordance with DSTU ISO 11464-2001. Laboratory and analytical studies were performed in a certified agrochemical laboratory of the IACR of NAAS. In the samples was determined: the content of easily hydrolyzed nitrogen - according to Cornfield method conducting hydrolysis of organic compounds with a solution of $1.0 \mathrm{n} \mathrm{NaOH}$ in Conway cups in a thermostat at $\mathrm{t} 28^{\circ} \mathrm{C}$ and titration with $0.02 \mathrm{n} \mathrm{H}_{2} \mathrm{SO}_{4}$ after 48 hours (DSTU 7863:2015); nitrate nitrogen - in salt suspension (1.0\% solution of alum-potassium alum) by ionometric method using ionomer I-160M and ion-selective electrodes (nitrate and silver-chloride comparison) (DSTU 4729:2007); ammonium nitrogen - by photocolorimetric method using Nessler's reagent and spectrophotometer Ulab 102UV (DSTU 4729:2007); exchange acidity $\left(\mathrm{pH}_{\mathrm{KCl}}\right)$ - by potentiometric method at a ratio soil : $\mathrm{KCl}$ solution $(1.0 \mathrm{n})$ equal 1:2.5 using a pH meter "pH-301" and glass electrodes (DSTU ISO 10390:2007); hydrolytic acidity - by the Kappen method in the extract of $1 \mathrm{n} \mathrm{CH}_{3} \mathrm{COONa}$ and titration with $0.1 \mathrm{n} \mathrm{NaOH}$ (DSTU 7537:2014); mobile aluminum - by the method of Sokolov, displacing $\mathrm{Al}^{3+}$ ions with a solution of $1 \mathrm{n} \mathrm{KCl}$ and titration with $0.01 \mathrm{n} \mathrm{NaOH}$ (GOST 26485-85). The accounting of the green mass yield of corn was carried out on each allotment in the phase of milk-wax ripeness.

Mathematical and statistical processing of the obtained research results and yield data was carried out using Microsoft Excel and Statistica 6.0. Data in tables and graphs are presented as arithmetic mean with standard deviation ( $x \pm S D)$.

\section{RESULTS AND DISCUSSION}

Fertilizers are one of the most expensive resources in corn cultivation, so it is very important to ensure that the increase in corn yield is not limited by a shortage, especially nitrogen, and reaches the highest yield (Gramig et al. 2017). After all, nitrogen fertilizers are one of the most important factors in corn production.

The timing and rate of nitrogen fertilizers application can affect the yield of corn, nitrogen uptake and efficiency of its use. Therefore, to optimize the corn harvest, there is a clear need to manage nitrogen nutrition in each specific location, in different soils and environments (Davies et al. 2020).

Among the mineral compounds of nitrogen, the main role in plant nutrition is played by nitrate and ammonium nitrogen of soil solution or colloids. These nitrogen compounds are dynamic in time, easily mobile, easily soluble and readily available. The total content of nitrate 
and ammonium nitrogen plays a major role in plant nutrition and is a diagnostic criterion for available nitrogen in the soil (Novoselov and Zavalin 1996). It is systematic observations of the dynamics of nitrogen compounds during the growth and development of corn that make it possible to set or adjust the doses of nitrogen fertilizers.

It is known that during the growing season of corn, the content of nitrates in the soil varies depending on the intensity of their use by plants. Their dynamics is closely related to the accumulation of dry matter by corn plants (Minkin 2019).

The central component of the global nitrogen cycle is nitrification (Gubry-Rangin et al. 2010). At one time it was assumed that the rate of nitrification on acidic soils is relatively low. However, recent studies claim that nitrification exists up to $\mathrm{pH} 3.0$. The rate of nitrification in acidic environment may be equal to or even higher than the rate of nitrification observed on neutral soils (Li et al. 2018).

Studies have shown that the content of mineral nitrogen compounds during the growing season of corn depended on fertilizing and liming systems. The most intensive accumulation

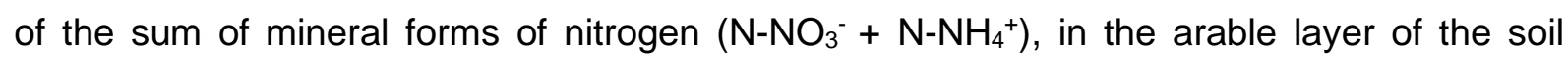
in the phase of $3-5$ leaves (134.1 $\mathrm{mg} \cdot \mathrm{kg}^{-1}$ of soil) was observed by the organo-mineral fertilizing system when used together in crop rotation $\mathrm{N}_{65} \mathrm{P}_{68} \mathrm{~K}_{68}, 10 \mathrm{t} \cdot \mathrm{ha}^{-1}$ of manure and $1.0 \mathrm{n} \mathrm{CaCO}_{3}$ by $\mathrm{Ha}$ (var. 7). The content of nitrate nitrogen is $84.9 \mathrm{mg} \cdot \mathrm{kg}^{-1}$ of soil, in the control it was $11.6 \mathrm{mg} \cdot \mathrm{kg}^{-1}$. With this organo-mineral fertilizing system, but with the background of $0.5 \mathrm{n}$ lime introduction (var. 6), the total content of mineral forms of nitrogen was $118.7 \mathrm{mg} \cdot \mathrm{kg}^{-1}$ of soil, of which nitrate nitrogen was $78.5 \mathrm{mg} \cdot \mathrm{kg}^{-1}$ (Table 1).

Under the mineral fertilizing system, when applying a one-and-a-half dose of mineral fertilizers with application of $\mathrm{N}_{180} \mathrm{P}_{135} \mathrm{~K}_{135}$ to corn (with the background of $1.5 \mathrm{n} \mathrm{CaCO}$ ), the amount of mobile nitrogen compounds was $132.3 \mathrm{mg} \cdot \mathrm{kg}^{-1}$ of soil, including nitrate $110.6 \mathrm{mg} \cdot \mathrm{kg}^{-1}$ of soil (var. 17, Table 1, Fig. 1).

The organic fertilizing system with application of $40 \mathrm{t} \cdot \mathrm{ha}^{-1}$ of manure under corn with the background of $1.0 \mathrm{n}$ of lime increases the content of the most available forms of nitrogen to $80.0 \mathrm{mg} \cdot \mathrm{kg}^{-1}$ of soil, while the content of nitrate nitrogen is $44.0 \mathrm{mg} \cdot \mathrm{kg}^{-1}$. With separate application of organic fertilizers and lime, the content of mineral nitrogen compounds decreases to 47.1 and $43.6 \mathrm{mg} \cdot \mathrm{kg}^{-1}$ of soil, respectively (including nitrate -1.98 and $1.83 \mathrm{mg} \cdot \mathrm{kg}^{-1}$ of soil). The low content of nitrate nitrogen in the soil when applying the manure onlyis explained by the fact that the nitrogen of the manure is mainly stored in organic form. It is less mineralized and passes more slowly into the soil solution in contrast to nitrogen fertilizers, where it is in soluble form. Liming of Albic Stagnic Luvisol significantly improves the reaction of the soil solution. As a result, the number of ammonifiers and nitrifiers bacteria increases. Therefore, the content of mobile mineral compounds in these conditions is higher than in the control, where the intensity of nitrification is low.

In the field the role of ammonia and nitrates in plant nutrition is far from the same. The value of soil absorbed ammonium as a source of nitrogen is less. The presence of a significant amount of absorbed ammonium in the soil does not mean a good supply of plants with this nutrient. It is known that on soils with medium and heavy particle size distribution and neutral reaction plants use the ammonium form of nitrogen better (Marchuk 2010). 
Table 1. Dynamics of nitrogen compounds in the soil under corn depending on the levels of fertilizing and liming IX rotation, $(x \pm S D, n=6)$

\begin{tabular}{|c|c|c|c|c|c|c|c|c|c|c|c|c|}
\hline \multirow{4}{*}{ No. var. } & \multicolumn{12}{|c|}{ Vegetation phases } \\
\hline & \multicolumn{4}{|c|}{ 3-5 leaves } & \multicolumn{4}{|c|}{ panicle ejection } & \multicolumn{4}{|c|}{ milk-wax ripeness } \\
\hline & $\mathrm{N}-\mathrm{NO}_{3}^{-}$ & $\mathrm{N}-\mathrm{NH}_{4}^{+}$ & $\begin{array}{c}\text { easily } \\
\text { hydrolyzed }\end{array}$ & $\begin{array}{l}\mathrm{N}-\mathrm{NO}_{3}{ }^{-} / \\
\mathrm{N}-\mathrm{NH}_{4}{ }^{+}\end{array}$ & $\mathrm{N}-\mathrm{NO}_{3}$ & $\mathrm{~N}-\mathrm{NH}_{4}$ & $\begin{array}{c}\text { easily } \\
\text { hydrolyzed }\end{array}$ & $\begin{array}{l}\mathrm{N}-\mathrm{NO}_{3}^{-} \text {- } \\
\mathrm{N}-\mathrm{NH}_{4}^{+}\end{array}$ & $\mathrm{N}-\mathrm{NO}_{3}$ & $\mathrm{~N}-\mathrm{NH}_{4}$ & $\begin{array}{c}\text { easily } \\
\text { hydrolyzed }\end{array}$ & 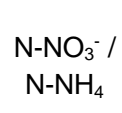 \\
\hline & \multicolumn{3}{|c|}{$\mathrm{mg} \cdot \mathrm{kg}^{-1}$ of soil } & & \multicolumn{3}{|c|}{$\mathrm{mg} \cdot \mathrm{kg}^{-1}$ of soil } & & \multicolumn{3}{|c|}{$\mathrm{mg} \cdot \mathrm{kg}^{-1}$ of soil } & \\
\hline 1 & $11.6 \pm 0.49$ & $24.4 \pm 0.42$ & $100.8 \pm 1.45$ & 0.47 & $11.2 \pm 0.21$ & $11.6 \pm 0.49$ & $82.6 \pm 1.08$ & 0.96 & $6.0 \pm 0.41$ & $6.6 \pm 0.49$ & $71.4 \pm 0.53$ & 0.91 \\
\hline 2 & $18.3 \pm 0.25$ & $25.3 \pm 1,06$ & $104.3 \pm 1.77$ & 0.72 & $16.0 \pm 0.82$ & $12.6 \pm 0.41$ & $84.0 \pm 1.03$ & 1.26 & $14.4 \pm 0.33$ & $8.0 \pm 0.82$ & $77.0 \pm 0.82$ & 1.80 \\
\hline 3 & $19.8 \pm 0.57$ & $27.3 \pm 1,06$ & $126.0 \pm 1.63$ & 0.72 & $17.6 \pm 0.54$ & $14.1 \pm 0.86$ & $89.0 \pm 0.82$ & 1.25 & $11.2 \pm 0.57$ & $9.0 \pm 0.41$ & $85.4 \pm 0.82$ & 1.24 \\
\hline 4 & $44.0 \pm 1.63$ & $36.0 \pm 1,63$ & $130.0 \pm 0.82$ & 1.22 & $32.0 \pm 1.03$ & $18.1 \pm 1,07$ & $101.5 \pm 1.23$ & 1.77 & $16.3 \pm 0.29$ & $9.6 \pm 0.49$ & $90.0 \pm 0.49$ & 1.70 \\
\hline 6 & $78.5 \pm 1.63$ & $40.2 \pm 1.72$ & $98.0 \pm 1.80$ & 1.95 & $44.4 \pm 1.14$ & $17.1 \pm 0.78$ & $93.8 \pm 0.65$ & 2.59 & $15.9 \pm 0.73$ & $9.1 \pm 0.45$ & $84.0 \pm 0.84$ & 1.74 \\
\hline 7 & $84.9 \pm 1.68$ & $49.2 \pm 0.45$ & $148.4 \pm 1.23$ & 1.73 & $57.6 \pm 0.49$ & $19.1 \pm 0.49$ & $103.6 \pm 0.90$ & 3.01 & $20.5 \pm 0.41$ & $16.6 \pm 0,52$ & $95.2 \pm 0.98$ & 1.23 \\
\hline 14 & $49.9 \pm 0.90$ & $36.2 \pm 1.72$ & $108.1 \pm 1.64$ & 1.38 & $27.4 \pm 0.37$ & $16.1 \pm 0.90$ & $86.8 \pm 0.62$ & 1.70 & $20.4 \pm 0.33$ & $11.6 \pm 0.50$ & $85.4 \pm 0.74$ & 1.76 \\
\hline 15 & $114.3 \pm 1.59$ & $33.8 \pm 0.81$ & $114.1 \pm 0.74$ & 3.38 & $71.6 \pm 0.50$ & $24.2 \pm 0.54$ & $88.9 \pm 0.74$ & 2.96 & $54.0 \pm 0.82$ & $15.2 \pm 0,32$ & $86.8 \pm 0.65$ & 3.55 \\
\hline 17 & $100.6 \pm 1.31$ & $31.7 \pm 0.62$ & $107.9 \pm 1.10$ & 3.17 & $51.2 \pm 0.29$ & $16.0 \pm 0.82$ & $81.4 \pm 0.33$ & 3.20 & $35.3 \pm 0.25$ & $13.6 \pm 0,37$ & $79.1 \pm 0.25$ & 2.60 \\
\hline $\begin{array}{l}\mathrm{LSD}_{05}, \\
\mathrm{mg} \cdot \mathrm{kg}^{-1}\end{array}$ & 3.1 & 2.4 & 6.2 & & 2.9 & 2.1 & 7.1 & & 2.6 & 2.3 & 6.7 & \\
\hline
\end{tabular}

LSD - least significant difference. 


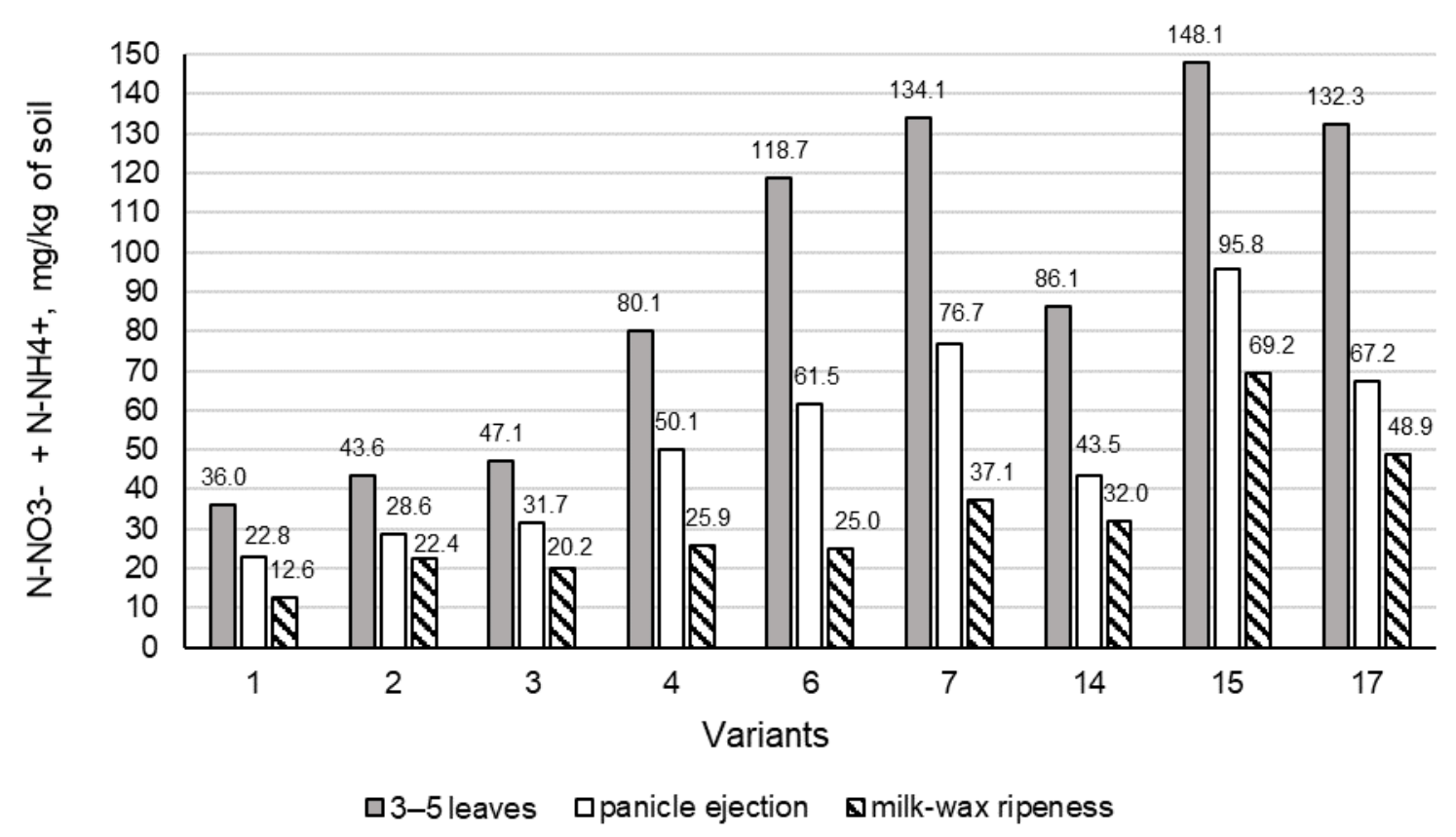

Fig. 1. Dynamics of mineral forms of nitrogen $\left(\mathrm{N}^{-N}{ }_{3}{ }^{-}+\mathrm{N}^{-} \mathrm{NH}_{4}{ }^{+}\right)$of the arable layer of soil under corn, depending on levels of fertilizing and liming IX rotation, $\mathrm{mg} \mathrm{kg}^{-1}$ of soil $(x \pm S D, n=6)$

However, this form of nitrogen compared to nitrate is less available to plants, especially on acidic soils. Because the main part of ammonium is in the soil in the absorbed state, and the acid reaction of the soil solution does not contribute to the nitrification process. That is, the ammoniacal form of nitrogen is ineffective at $\mathrm{pH}$ below 5.0.

Because the ammonium form of nitrogen is well absorbed by plants and microbes, and nitrate is easily lost from the ecosystem, the rapid and direct conversion of $\mathrm{NO}_{3}{ }^{-}$to $\mathrm{NH}_{4}{ }^{+}$ through dissimilation recovery of nitrates to ammonium can play an important role in ecosystem nitrogen conservation (Yin et al. 2002).

On the other hand, increasing the fixation of ammonium nitrogen can be a way to create a pool of nitrogen in soils to optimize crop accumulation and minimize nitrogen loss to the environment ( $\mathrm{Liu}$ et al. 2008), because $\mathrm{NH}_{4}{ }^{+}$ions after penetration into clay layers are excluded from nitrification and thus protected from leaching (Nieder et al. 2011).

The conducted researches have established that under corn, depending on the norms of the applied fertilizers and doses of lime in the crop rotation, the supply of plants with ammonium nitrogen is different.

The most intensive accumulation of ammonium nitrogen in the soil under corn was observed in the variants of organo-mineral fertilizing with the background of liming $1.0 \mathrm{n} \mathrm{CaCO}_{3}$ by $\mathrm{Ha}$ with direct application of mineral fertilizers at a dose of $\mathrm{N}_{120} \mathrm{P}_{90} \mathrm{~K}_{90}$ and manure at a dose of $40 \mathrm{t} \cdot \mathrm{ha}^{-1}$. The content of ammonium nitrogen in the phase of 3-5 leaves was $49.2 \mathrm{mg} \cdot \mathrm{kg}^{-1}$ of soil. Under organo-mineral fertilizing with the background of liming $0.5 \mathrm{n} \mathrm{CaCO}_{3}$ by $\mathrm{Ha}$, the ammonium nitrogen content decreased to 40.2 (Table 1).

In the variant of the mineral fertilization system, the highest content of ammonium nitrogen (33.8 $\mathrm{mg} \cdot \mathrm{kg}^{-1}$ of soil) in the arable soil layer was observed by applying dose of NPK for 50 years, and in the years of research $-\mathrm{N}_{120} \mathrm{P}_{90} \mathrm{~K}_{90}$ under corn (var. 15). However, 
it should be noted that with unilateral long-term application of mineral fertilizers on acidic Albic Stagnic Luvisol, along with the accumulation of nitrogen compounds, the acidity increased to $4.12 \mathrm{pH}_{\mathrm{KCl}}, \mathrm{Ha}$ increased to $4.6 \mathrm{mg}-\mathrm{eq} / 100 \mathrm{~g}$ of soil and content of mobile aluminum compounds - up to $75.0 \mathrm{mg} \cdot \mathrm{kg}^{-1}$ of soil. This led to blocking of the enzyme systems activity, reduced processes of absorption and transformation of nutrients and, as a consequence, the formation of the corn crop was lower than in the control without fertilizers (Tables 2 and 3 ).

In the variants of control, after liming and manuring, the content of ammonium nitrogen was the lowest and in the phase of 3-5 leaves consisted of $24.4-25.3-27.3 \mathrm{mg} \cdot \mathrm{kg}^{-1}$ of soil. In general, according to the variants of the experiment, the level of ammonium nitrogen varied adequately to the amount of fertilizer applied (Table 1).

With the growth and development of corn plants, a decrease in the content of ammonium nitrogen in the arable layer of the soil was observed in all variants of the experiment, due to its absorption by plants. In crop rotation by joint introduction of one dose of mineral fertilizers, $10 \mathrm{t} \cdot \mathrm{ha}^{-1}$ of manure and $1,0 \mathrm{n}$ of lime in a phase of 3-5 leaves, the content of ammonium nitrogen was $49,2 \mathrm{mg} \cdot \mathrm{kg}^{-1}$ of soil, in a phase of panicle ejection $-19,1 \mathrm{mg} \cdot \mathrm{kg}^{-1}$. At the end of the growing season in the phase of milk-wax ripeness $-16.6 \mathrm{mg} \cdot \mathrm{kg}^{-1}$ of soil.

An important diagnostic indicator that characterizes the degree of nitrification and the peculiarities of nitrogen conversion processes in soil, is the ratio $\mathrm{N}-\mathrm{NO}_{3}^{-} / \mathrm{N}-\mathrm{NH}_{4}{ }^{+}$. This indicator, as shown by studies at the optimum temperature of the growing season and a favorable mode of humidification, was quite high in variants with different levels of fertilizers - 1.23-3.55 compared to the control without fertilizers - 0.47-0.96. This dependence should be taken into account, especially in recent years in the context of climate change, which is often accompanied by uneven distribution of precipitation and their torrential nature with increasing air temperature. Under such extreme conditions, significant losses of nitrate nitrogen due to leaching are possible.

The lowest ratio ${\mathrm{N}-\mathrm{NO}_{3}}^{-} / \mathrm{N}^{-} \mathrm{NH}_{4}{ }^{+}(0.47)$ in the phase of 3-5 leaves on the control without fertilizers indicates both unsatisfactory nitrogen regime and low nitrification capacity of Albic Stagnic Luvisol. With the joint application of manure and mineral fertilizers in the crop rotation with the background of liming, the intensive use of nitrogen compounds for the formation of high productivity of corn increases due to the more intensive nitrification process.

Unilateral increase of the ratio $\mathrm{N}-\mathrm{NO}_{3}{ }^{-} / \mathrm{N}^{-} \mathrm{NH}_{4}{ }^{+}$in the variant with mineral fertilizing is caused first of all by the mineral fertilizers which at high acidity of soil solution are not able to transform into a crop (var. 15, Table 2).

By the application of mineral fertilizers in high doses with the background of liming $1.5 \mathrm{n} \mathrm{CaCO}_{3}$ by $\mathrm{Ha}$, the acidity level decreased to 5.81 units of $\mathrm{pH}_{\mathrm{KCl}}$, Ha to $1.73 \mathrm{mmol} \cdot \mathrm{kg}^{-1}$ of soil, and the content of mobile aluminum compounds to $4.9 \mathrm{mg} \cdot \mathrm{kg}^{-1}$ of soil, which contributed to better nitrification, the formation of high productivity of the agroecosystem $\left(63.4 \mathrm{t} \cdot \mathrm{ha}^{-1}\right)$, which once again emphasizes the exceptional importance of liming on Albic Stagnic Luvisols of the Western Forest-Steppe (var. 17, Table 3). 
Table 2. Physico-chemical properties of the arable layer of Albic Stagnic Luvisol depending on different fertilizing systems, end of the IX rotation $(x \pm S D, n=6)$

\begin{tabular}{|c|c|c|c|c|}
\hline No. var & Variants & $\mathrm{pH \kappa Cl}$ & $\begin{array}{c}\mathrm{Ha}, \\
\mathrm{mmol} \cdot \mathrm{kg}^{-1} \\
\text { of soil }\end{array}$ & $\begin{array}{c}\text { Movable } \\
\text { aluminum, } \\
\mathrm{mg} \cdot \mathrm{kg}^{-1} \text { of soil }\end{array}$ \\
\hline 1 & Without fertilizers (control) & $4.30 \pm 0.15$ & $4.49 \pm 0.44$ & $60.7 \pm 0.25$ \\
\hline 2 & $\mathrm{CaCO}_{3}, 1.0 \mathrm{n}$ by Ha & $5.60 \pm 0.17$ & $2.09 \pm 0.46$ & $3.6 \pm 0.50$ \\
\hline 3 & Manure, $10 \mathrm{t} \cdot \mathrm{ha}^{-1}$ & $4.58 \pm 0.12$ & $2.75 \pm 0.63$ & $10.1 \pm 1.00$ \\
\hline 4 & $\begin{array}{l}\text { Manure, } 10 \mathrm{t} \cdot \mathrm{ha}^{-1}+\mathrm{CaCO}_{3} \\
1.0 \mathrm{n} \mathrm{by} \mathrm{Ha}\end{array}$ & $5.59 \pm 0.12$ & $1.79 \pm 0.29$ & $4.2 \pm 1.35$ \\
\hline 6 & $\begin{array}{l}\mathrm{N}_{65} \mathrm{P}_{68} \mathrm{~K}_{68}+\text { manure, } 10 \mathrm{t} \cdot \mathrm{ha}^{-1}+ \\
\mathrm{CaCO}_{3}, 0.5 \mathrm{n} \text { by Ha }\end{array}$ & $4.97 \pm 0.11$ & $2.97 \pm 0.15$ & $9.1 \pm 0.40$ \\
\hline 7 & $\begin{array}{l}\mathrm{N}_{65} \mathrm{P}_{68} \mathrm{~K}_{68}+\text { manure, } 10 \mathrm{t} \cdot \mathrm{ha}^{-1}+ \\
\mathrm{CaCO}_{3}, 1.0 \mathrm{n} \mathrm{by} \mathrm{Ha}\end{array}$ & $5.38 \pm 0.18$ & $2.28 \pm 0.36$ & $4.2 \pm 1.15$ \\
\hline 14 & $\begin{array}{l}\mathrm{N}_{30} \mathrm{P}_{34} \mathrm{~K}_{34}+15 \mathrm{t} \cdot \mathrm{ha}^{-1} \text { of manure }+1.5 \mathrm{n} \\
\mathrm{CaCO}_{3} \text { by Ha }\end{array}$ & $5.26 \pm 0.16$ & $2.51 \pm 0.41$ & $9.7 \pm 1.00$ \\
\hline 15 & $\mathrm{~N}_{65} \mathrm{P}_{68} \mathrm{~K}_{68}$ & $4.12 \pm 0.09$ & $4.69 \pm 0.47$ & $75.0 \pm 1,70$ \\
\hline \multirow[t]{2}{*}{17} & $\begin{array}{l}\mathrm{N}_{105} \mathrm{P}_{101} \mathrm{~K}_{101}+\mathrm{CaCO}_{3} \\
1.5 \mathrm{n} \text { by Ha}\end{array}$ & $5.81 \pm 0.21$ & $1.73 \pm 0.53$ & $4.9 \pm 1.00$ \\
\hline & LSD05 & 0.21 & 0.11 & 0.65 \\
\hline
\end{tabular}

Given that nitrogen of easily hydrolyzed organic compounds is the closest reserve of mineral nitrogen and in agricultural use can be both accumulated and consumed from the soil (Tsentylo and Tsyuk 2019), it is important to investigate its change depending on different fertilizing systems.

In our studies, the level of easily hydrolyzed nitrogen in the soil under corn varied depending on the fertilizing systems similar to the change in the content of nitrate and ammonium nitrogen. Thus, in the control variants with the use of lime, the content of easily hydrolyzed nitrogen in the arable layer was low $-100.8-104.3 \mathrm{mg} \cdot \mathrm{kg}^{-1}$ of arable soil layer (Table 1).

Obviously, easily hydrolyzed nitrogen compounds in the conditions of Albic Stagnic Luvisol, formed during the decomposition of organic fertilizers and plant residues, are primarily used as a nutritional source.

At the beginning of the growing season by the organo-mineral fertilizing system with the introduction of one dose of mineral fertilizers $\mathrm{N}_{65} \mathrm{P}_{68} \mathrm{~K}_{68}$ and $10 \mathrm{t} \cdot \mathrm{ha}^{-1}$ of manure with the background of liming with $1.0 \mathrm{n} \mathrm{CaCO}_{3}$, the content of easily hydrolyzed nitrogen in the phase of $3-5$ leaves increased to $148.4 \mathrm{mg} \cdot \mathrm{kg}^{-1}$ of soil. By this fertilizing system with the introduction of half the dose of lime, the level of easily hydrolyzed nitrogen decreased to $98.0 \mathrm{mg} \cdot \mathrm{kg}^{-1}$ of soil. The highest nitrogen content according to Cornfield $\left(114,1 \mathrm{mg} \cdot \mathrm{kg}^{-1}\right.$ of soil) was observed in the variant with systematic application of mineral fertilizers (Table 1).

Nitrogen content in Albic Stagnic Luvisol is minimal compared to phosphorus and potassium. In the phases of panicle ejection and milk-wax ripeness as plants are growing and developing, on higher fertilizer backgrounds they form much larger yields, easily hydrolyzed organic compounds are more susceptible to nitrification, mineralization, and more intensive used by plants. Therefore, their content in the soil is reduced in all variants of the experiment.

The criterion of the effectiveness of developed and improved agronomic measures for growing crops is productivity (Kramaryov and Artemenko 2016). Systematic fertilization and periodic liming in crop rotation improves the nutrient regime, physicochemical properties and 
reduces soil acidity. It makes possible to obtain in conditions of acidic Albic Stagnic Luvisols high and stable yields of corn in the milk-wax ripeness phase (Table 3).

Studies have shown that the yield of the accumulated mass in the phase of milk-wax ripeness of corn depended on the level and type of fertilizer: a higher level of nutrition led to a higher yield. That is why the highest yields of corn $\left(74.3,67.1\right.$ and $\left.68.5 \mathrm{t} \cdot \mathrm{ha}^{-1}\right)$ were provided by organo-mineral fertilizing systems with application of $40 \mathrm{t} \cdot \mathrm{ha}^{-1}$ of manure, $\mathrm{N}_{120} \mathrm{P}_{90} \mathrm{~K}_{90}$ and $\mathrm{N}_{90} \mathrm{P}_{45} \mathrm{~K}_{90}$ with the background of liming with one-and-a-half doses of lime. In this case, the $\mathrm{pH}_{\mathrm{KCl}}$ is respectively $5.38-4.97-5.26, \mathrm{Ha} 2.28-2.97 \mathrm{mmol} \cdot \mathrm{kg}^{-1}$ of soil, the content of mobile aluminum compounds $4.2-9.1-9.7 \mathrm{mg} \cdot \mathrm{kg}^{-1}$ of soil (Table 2 and 3 ).

Table 3. Yield of corn in the phase of milk-wax ripeness with long-term use of fertilizers and lime, IX rotation $(x \pm S D, n=6)$

\begin{tabular}{|c|c|c|c|c|c|}
\hline \multirow{2}{*}{$\begin{array}{l}\text { No. } \\
\text { var. }\end{array}$} & \multirow[t]{2}{*}{ Variant } & \multirow[t]{2}{*}{ Corn fertilizers } & \multirow{2}{*}{$\begin{array}{c}\text { Yield, } \\
\mathrm{t} \cdot \mathrm{ha}^{-1}\end{array}$} & \multicolumn{2}{|c|}{$\begin{array}{l}\text { Increase to } \\
\text { control }\end{array}$} \\
\hline & & & & $t \cdot h a^{-1}$ & $\%$ \\
\hline 1 & Without fertilizers (control) & - & $25.2 \pm 0.65$ & - & - \\
\hline 2 & $\mathrm{CaCO}_{3}, 1.0 \mathrm{n}$ by $\mathrm{Ha}$ & - & $36.0 \pm 2.77$ & 10.8 & 42.9 \\
\hline 3 & Manure, $10 \mathrm{t} \cdot \mathrm{ha}^{-1}$ & manure, $40 \mathrm{t} \cdot \mathrm{ha}^{-1}$ & $39.9 \pm 3.34$ & 14.7 & 58.3 \\
\hline 4 & $\begin{array}{l}\text { Manure, } 10 \mathrm{t} \cdot \mathrm{ha}^{-1}+\mathrm{CaCO}_{3}, 1.0 \mathrm{n} \\
\text { by Ha }\end{array}$ & manure, $40 \mathrm{t} \cdot \mathrm{ha}^{-1}$ & $49.4 \pm 3.49$ & 24.2 & 96.0 \\
\hline 6 & $\begin{array}{l}\mathrm{N}_{65} \mathrm{P}_{68} \mathrm{~K}_{68}+\text { manure, } 10 \mathrm{t} \cdot \mathrm{ha}^{-1}+ \\
\mathrm{CaCO}_{3}, 0.5 \mathrm{n} \text { by Ha }\end{array}$ & $\begin{array}{c}\text { manure, } 40 \mathrm{t} \cdot \mathrm{ha}^{-1}+ \\
\mathrm{N}_{120} \mathrm{P}_{90} \mathrm{~K}_{90} \\
\end{array}$ & $67.1 \pm 1.64$ & 41.9 & 166.3 \\
\hline 7 & $\begin{array}{l}\mathrm{N}_{65} \mathrm{P}_{68} \mathrm{~K}_{68}+\text { manure,10 t } \cdot \mathrm{ha}^{-1}+ \\
\mathrm{CaCO}_{3}, 1.0 \mathrm{n} \text { by Ha }\end{array}$ & $\begin{array}{c}\text { manure, } 40 \mathrm{t} \cdot \mathrm{ha}^{-1}+ \\
\mathrm{N}_{120} \mathrm{P}_{90} \mathrm{~K}_{90}\end{array}$ & $74.3 \pm 0.90$ & 49.1 & 194.8 \\
\hline 14 & $\begin{array}{l}\mathrm{N}_{30} \mathrm{P}_{34} \mathrm{~K}_{34}+15 \mathrm{t} \cdot \mathrm{ha}^{-1} \text { of manure }+ \\
1.5 \mathrm{n} \mathrm{CaCO}_{3} \text { by Ha }\end{array}$ & $\begin{array}{c}\text { manure, } 40 \mathrm{t} \cdot \mathrm{ha}^{-1}+ \\
\mathrm{N}_{90} \mathrm{P}_{45} \mathrm{~K}_{90} \\
\end{array}$ & $68.5 \pm 0.99$ & 43.3 & 171.8 \\
\hline 15 & $\mathrm{~N}_{65} \mathrm{P}_{68} \mathrm{~K}_{68}$ & $\mathrm{~N}_{120} \mathrm{P}_{90} \mathrm{~K}_{90}$ & $30.3 \pm 2.13$ & 5.1 & 20.2 \\
\hline \multirow[t]{2}{*}{17} & $\begin{array}{l}\mathrm{N}_{105} \mathrm{P}_{101} \mathrm{~K}_{101}+\mathrm{CaCO}_{3} \\
1.5 \mathrm{n} \text { by Ha }\end{array}$ & $\mathrm{N}_{180} \mathrm{P}_{135} \mathrm{~K}_{135}$ & $63.4 \pm 1.23$ & 38.2 & 151.6 \\
\hline & $\mathrm{LSD}_{05}, \mathrm{t} \cdot \mathrm{ha}^{-1}$ & & 1.56 & & \\
\hline
\end{tabular}

The organic system of fertilizing with application of $40 \mathrm{t} \cdot \mathrm{ha}^{-1}$ of manure ensured formation of the harvest at the level of $39.9 \mathrm{t} \cdot \mathrm{ha}^{-1}$. Chemical melioration, reducing the acidity of the soil $\mathrm{pH}_{\mathrm{KCl}}$ to 4.58 , Ha to $2.75 \mathrm{mmol} \mathrm{kg}^{-1}$ of soil, content of mobile aluminum compounds to $10.1 \mathrm{mg} \cdot \mathrm{kg}^{-1}$ of soil, makes it possible to increase the yield of corn to $36.0 \mathrm{t} \cdot \mathrm{ha}^{-1} \mathrm{due}$ to the mobilization of soil nutrients. With the joint application of organic and lime fertilizers, the yield increased to $49.4 \mathrm{t} \cdot \mathrm{ha}^{-1}$.

In studies (Masliyov et al. 2018) with the use of organo-mineral and organic fertilizing systems, the yield of corn for silage was significantly reduced by 6.4 and $37 \%$, respectively, compared with the use of mineral fertilizing system.

In our studies, with long-term use in crop rotation of the mineral fertilizing system on acidic Albic Stagnic Luvisol, along with the accumulation of nitrogen compounds, there was an increase in soil acidity: $\mathrm{pH}_{\mathrm{KCl}}$ to 4.12 , Ha to $4.69 \mathrm{mmol} \cdot \mathrm{kg}^{-1}$ of soil and the content of mobile aluminum compounds up to $75.0 \mathrm{mg} \cdot \mathrm{kg}^{-1}$. Due to blocking of the enzyme systems activity in a strongly acidic environment, the processes of absorption and transformation of nutrients are reduced and, as a result, a low yield of corn is formed $-30.3 \mathrm{t} \cdot \mathrm{ha}^{-1}$ (Table 3 ). 
The mineral fertilizing system on acidic soil was effective only with the background of periodic application of $1.5 \mathrm{n} \mathrm{CaCO}_{3}$, while the productivity was quite high and amounted up to $63.4 \mathrm{t} \cdot \mathrm{ha}^{-1}$ (var. 17, Table 3).

\section{CONCLUSIONS}

In the conditions of the Western Forest-Steppe in short-rotational crop rotation on Albic Stagnic Luvisol, the highest productivity of corn $-73.0 \mathrm{t} \cdot \mathrm{ha}^{-1}$ - in the IX rotation is formed by organo-mineral fertilizing system with systematic joint application of manure $10 \mathrm{t} \cdot \mathrm{ha}^{-1}$, $\mathrm{N}_{65} \mathrm{P}_{68} \mathrm{~K}_{68}$ with the background of periodic liming of $1.0 \mathrm{n} \mathrm{CaCO}$ by hydrolytic acidity. This fertilizing system greatly improves the nitrogen balance, promotes the nitrification processes, increases the content of mineral nitrogen compounds throughout the growing season of corn.

Unilateral long-term use of mineral fertilizing system on acidic Albic Stagnic Luvisol along with the accumulation of nitrogen compounds, increases the acidity and content of mobile aluminum compounds. This leads to blocking the activity of enzyme systems, reducing absorption and transformation of nutrients. In this case a yield of corn is low, at the level of control without fertilizers.

\section{REFERENCES}

Centilo L.V., Tsyuk O.A. 2019. Azotnyi rezhym chornozemu typovoho zalezhno vid udobrennia i obrobitku gruntu [Nitrogen regime of typical chernozem depending on fertilizer and tillage]. Biores. Pryrodokoryst. 11(12), 107-114. DOI: http://dx.doi.org/10.31548/bio2019.01.012. [in Ukrainian]

Davies B., Coulter J.A., Pagliari P.H. 2020. Timing and rate of nitrogen fertilization influence maize yield and nitrogen use efficiency. PLOS ONE 15(5), e0233674, https://doi.org/10.1371/ /journal.pone.0233674.

Gramig B.M., Massey R., Yun S.D. 2017. Nitrogen application decision-making under climate risk in the U.S. Corn Belt. Climate Risk Manag. 15, 82-89, https://doi.org/10.1016/j.crm.2016.09.001.

Gubry-Rangin C., Nicol G.W., Prosser J.I. 2010. Archaea rather than bacteria control nitrification in two agricultural acidic soils. FEMS Microbiol. Ecol. 74(3), 566-574, https://doi.org/10.1111/ /j.1574-6941.2010.00971.x.

IUSS Working Group WRB. 2015. World Reference Base for Soil Resources 2014, update 2015 International soil classification system for naming soils and creating legends for soil maps. World Soil Resources Reports 106. Rome, FAO, http://www.fao.org/3/i3794en//3794en.pdf.

Klimchuk O.V. 2009. Selektsiia ta vyroshchuvannia kukurudzy v umovakh monokultury [Selection and cultivation of corn in monoculture]. Vinnytsia, PP Baliuk I.B., 216. [in Ukrainian]

Klimchuk O.V., Skoruk O.P. 2011. Perspektyvni napriamky vyroshchuvannia kukurudzy dlia vykorystannia na enerhetychni potreby [Promising directions for growing corn for energy use]. Zbirnyk naukovykh prats VNAU, Ekonomichni nauky 1(48), 67-73. [in Ukrainian]

Kolos M.O. 2017. Doslidzhennia azotnoho rezhymu ta humusnoho stanu chornozemiv zvychainykh zalezhno vid tekhnolohii obrobitku gruntu [Research of nitrogen regime and humus state of common chernozems depending on tillage technologies]. Sci. Rise 12 (41), 26-29. [in Ukrainian]

Kramaryov S.M., Artemenko S.F. 2016. Produktyvnist kukurudzy v sivozminakh korotkykh rotatsii iz soieiu v umovakh pivnichnoho stepu Ukrainy [Productivity of corn in crop rotations of short rotations with soybean in the conditions of the northern steppe of Ukraine]. Visnyk Dnipropetrovskoho derzhavnoho ahrarno-ekonomichnoho universytetu, silskohospodarska ekolohiia, ahronomichni nauky 4(42), 67-71. [in Ukrainian] 
Li Y., Chapman S.J., Nicol G.W., Yao H. 2018. Nitrification and nitrifiers in acidic soils. Soil Biol. Biochem. 116, 290-301, https://doi.org/10.1016/j.soilbio.2017.10.023.

Liu Y.-L., Zhang B., Li C.L., Hu F., Velde B. 2008. Long-term fertilization influences on clay mineral composition and ammonium adsorption in rice paddy soils. Soil Sci. Soc. Am. J. 72(6), 1580-1590, https://doi.org/10.2136/sssaj2007.0040.

Marchuk I.U. 2010. Problemy azotu v zemlerobstvi [Problems of nitrogen in agriculture]. Propozitsiya 1, 62-68. [in Ukrainian]

Masliyov S.V., Matsay N. Yu., Tsygankova N.A., Sakhno M.A. 2018. Vplyv poperednykiv, obrobitku gruntu ta dobryv na urozhai i yakist zerna kukurudzy $v$ umovakh Luhanskoi oblasti [Influence of predecessors, tillage and fertilizers on the yield and quality of corn grain in the Luhansk region]. Visnyk Poltavskoi derzhavnoi ahrarnoi akademii 4, 18-23. DOI 10.31210 / visnyk2018.04.02. [in Ukrainian]

Minkin M.V., Berdnikov O.G., Minkina G.O. 2019. Formuvannia produktyvnosti kukurudzy na zerno zalezhno vid zhyvlennia ta hustoty stoiannia $v$ umovakh pivdnia Ukrainy [Formation of productivity of corn on grain depending on a food and density of standing in the conditions of the south of Ukraine]. Tavriiskyi naukovyi visnyk 106, 103-109. [in Ukrainian]

Nieder R., Benbi D.K., Scherer, H.W. 2011. Fixation and defixation of ammonium in soils: a review. Biol. Fertil. Soils 47, 1-14, https://doi.org/10.1007/s00374-010-0506-4.

Novoselov S.I., Zavalin A.A. 1996. Ekspress-metod opredeleniya nitratnoho azota v pochv. [Express method for the determination of nitrate nitrogen in the soil]. Ahrokhymyia 6, 96-102. [in Russia]

Tanchik S.P., Tsentilo L.V., Tsyuk O.A. 2019. Vplyv udobrennia ta obrobitku gruntu na vrozhainist kultur sivozminy [Influence of fertilizer and tillage on crop yields]. Visnyk ahrarnoi nauky 8, 11-16. DOI: https://doi.org/10.31073/agrovisnyk201908-02. [in Ukrainian]

Tsentylo L.V., Tsyuk O.A. 2019. Azotnyi rezhym chornozemu typovoho zalezhno vid udobrennya i obrobitku gruntu [Nitrogate mode of blacksmith type depending on growth adjustment and processing]. Bioresursy i pryrodokorystuvannya 11(1-2), 107-114, https://doi.org/10.31548/ /bio2019.01.012. [in Ukrainian]

Yin S.X., Chen D., Chen L.M., Edis R. 2002. Dissimilatory nitrate reduction to ammonium and responsible microorganisms in two Chinese and Australian paddy soils. Soil Biol. Biochem. 34(8), 1131-1137, https://doi.org/10.1016/S0038-0717(02)00049-4. 
